\title{
Recurrent Monosomies Confirmed by Interphase FISH in Three Chronic Myeloid Leukemia Cases
}

\author{
Üç Kronik Miyeloid Lösemi Olgusunda İnterfaz FISH ile \\ Doğrulanan Tekrarlayan Monozomiler
}

Yelda Tarkan Argüden1, Dilhan Kuru1, Ayşe Çırakoğlu1, Şükriye Yılmaz1, Şeniz Öngören Aydın², Cem Muhlis Ar², Ayhan Deviren'1, Teoman Soysal2, Seniha Hacıhanefioğlu1

1İstanbul University Cerrahpaşa Faculty of Medicine, Department of Medical Biology, İstanbul, Turkey

2istanbul University Cerrahpaşa Faculty of Medicine, Department of Internal Medicine, Division of Hematology, İstanbul, Turkey

To the Editor,

Although chronic myeloid leukemia (CML) is characterized by the Philadelphia $(\mathrm{Ph})$ chromosome, which is the result of $\mathrm{t}(9 ; 22)$ (q34; $\mathrm{q} 11)$ or its variants, $10 \%-20 \%$ of cases have additional cytogenetic abnormalities. The most common additional abnormalities are loss of the $\mathrm{Y}$ chromosome, $+8,+\mathrm{Ph}$, and $\mathrm{i}(17 \mathrm{q})$. Since these additional chromosome abnormalities are signs of disease progression, it is important to perform cytogenetic analyses periodically in patients with CML [1].

We have published our results on clonal chromosome abnormalities other than the $\mathrm{Ph}$ chromosome in $\mathrm{Ph}+$ and $\mathrm{Ph}$ - cells of CML patients who were followed in our center a few years ago [2,3]. Monosomies were the most frequently observed chromosome abnormalities in these reports. In some cases, there were recurrent monosomies in more than one sample. To evaluate the significance of these recurrent monosomies, we performed fluorescence in situ hybridization (FISH) analysis for 3 of the previously reported patients with recurrent monosomies. Informed consent was obtained before the study. For FISH testing, chromosomes 8, 10, 17, and 20 were selected, since they had been the most common monosomies in our earlier publications.

All 3 patients in this study were under imatinib therapy except for patient 2, who was receiving interferon at the time of the first sampling.
Conventional cytogenetic techniques were performed to examine the marrow samples. GTL-banded metaphases were examined according to International System for Human Cytogenetic Nomenclature guidelines [4]. Twenty metaphases were studied whenever possible. Cytocell Aquarius alpha satellite probes were used according to the manufacturer's instructions for FISH. Two hundred interphase cells were counted by 2 different researchers. Normal karyotyped blood or marrow samples were used as control cases. Results of the cytogenetic and FISH analyses are given in Table 1.

In the first 3 samples of patient 1, monosomy of chromosomes 8, 10, and 20 was confirmed by FISH. In the fourth sample of this patient, we performed FISH for chromosomes 10 and 20 despite their absence in the karyotype to see whether there was a hidden monosomy that we could not show by karyotyping. FISH indeed revealed a hidden monosomy for chromosome 20, but not for chromosome 10 . In the first 2 samples of patient 2, monosomy of chromosome 17 was observed in cytogenetic analysis and confirmed by FISH. However, in the third sample, -17 could be shown neither in the karyotype nor by FISH. Notably, percentages of -17 obtained by cytogenetics and FISH were compatible in each of the samples. In the first sample, -17 was detected cytogenetically in 3 out of 12 cells (25\%), and it was found in $46 \%$ of the interphases by FISH. In the second sample, -17 was found in $12 \%$ and $31 \%$ of the cells in cytogenetic and FISH analysis, respectively. In the third, it was absent

Address for Correspondence: Yelda Tarkan ARGÜDEN, M.D.,

İstanbul University Cerrahpaşa Faculty of Medicine, Department of Medical Biology, İstanbul, Turkey

Phone: +902124143034 E-mail: yeldata@istanbul.edu.tr

Received/Geliş tarihi : September 22, 2014

Accepted/Kabul tarihi : October 15, 2014 
Table 1. Cytogenetic and fluorescence in situ hybridization results.

\begin{tabular}{|c|c|c|c|c|c|}
\hline \multirow[t]{2}{*}{$\begin{array}{l}\text { Case } \\
\text { no. }\end{array}$} & \multirow[t]{2}{*}{$\begin{array}{l}\text { Sample } \\
\text { no. }\end{array}$} & \multirow[t]{2}{*}{ Cytogenetic Results } & \multirow{2}{*}{$\begin{array}{l}\text { Chromosome } \\
\text { numbers } \\
\text { analyzed by } \\
\text { FISH }\end{array}$} & \multicolumn{2}{|c|}{$\begin{array}{l}\text { Monosomy percentages } \\
\text { by FISH }\end{array}$} \\
\hline & & & & $\begin{array}{l}\text { Cases, } \\
\%\end{array}$ & $\begin{array}{l}\text { Controls, } \\
\%\end{array}$ \\
\hline \multirow[t]{4}{*}{ Case 1} & 1 & $\begin{array}{l}38 \sim 46, X,-Y[4], t(9 ; 22)(q 34 ; q 11)[6],-10[4],-15 \\
{[4],-16[3][c p 15] / 46, X Y[8]}\end{array}$ & 10 & 30 & 7 \\
\hline & 2 & $\begin{array}{l}37 \sim 47, \mathrm{XY},-\mathrm{Y}[3],-3[3],-7[4],-8[3],-9[3] \\
-10[4],-11[3],-14[3],-15[3],-18[4],-20[4] \\
+\operatorname{mar} 1[3],+\operatorname{mar} 2[2][\mathrm{cp} 16] / 46, \mathrm{XY}[13]\end{array}$ & $\begin{array}{l}10 \\
20\end{array}$ & $\begin{array}{l}16.5 \\
40\end{array}$ & $\begin{array}{l}7 \\
14\end{array}$ \\
\hline & 3 & $\begin{array}{l}35 \sim 45, \mathrm{XY},-4[3],-8[4],-9[3],-10[5],-13[6] \\
-14[3],-15[5],-16[4],-18[3],-21[3],-22[3] \\
{[\mathrm{cp} 12] / 46, \mathrm{XY}[6]}\end{array}$ & $\begin{array}{l}8 \\
10\end{array}$ & $\begin{array}{l}12 \\
14\end{array}$ & $\begin{array}{l}6.4 \\
7\end{array}$ \\
\hline & 4 & $46, \mathrm{XY}, \mathrm{t}(9 ; 22)[3] / 46, \mathrm{XY}[13]$ & $\begin{array}{l}10^{*} \\
20^{*}\end{array}$ & $\begin{array}{l}5.5 \\
43.5\end{array}$ & $\begin{array}{l}7 \\
14\end{array}$ \\
\hline \multirow[t]{3}{*}{ Case 2} & $1 * *$ & $\begin{array}{l}\text { 39 46,XX, t(9;22) (q34;q11) [12], -17 [3], -21 [3] } \\
\text { [cp12] }\end{array}$ & 17 & 46 & 15.6 \\
\hline & 2 & $\begin{array}{l}41 \sim 46, X X,-9[3], t(9 ; 22)(\mathrm{q} 34 ; \mathrm{q} 11)[25],-14[5], \\
-15[4],-17[3],-18[4],-21[3][\mathrm{cp} 25]\end{array}$ & 17 & 31 & 15.6 \\
\hline & 3 & $\begin{array}{l}35 \sim 46, \mathrm{XX},-3[5],-7[4],-8[5], \mathrm{t}(9 ; 22)(\mathrm{q} 34 ; \mathrm{q} 11) \\
{[18],-10[3],-12[3],-13[5],-15[4],-19[3],-20} \\
{[6],-21[4],-22[6][\mathrm{cp} 18]}\end{array}$ & $\begin{array}{l}8 \\
10 \\
17^{*} \\
20\end{array}$ & $\begin{array}{l}9 \\
9 \\
11 \\
15\end{array}$ & $\begin{array}{l}6.4 \\
7 \\
15.6 \\
14\end{array}$ \\
\hline \multirow[t]{2}{*}{ Case 3} & 1 & $\begin{array}{l}44 \sim 38, \mathrm{XY},-6[3],-8[5],-20[4][\mathrm{cp} 8] / 32, \mathrm{X},+1,+7, \\
+10,+19,+20[\mathrm{cp} 2] / 46, \mathrm{XY}[9]\end{array}$ & $\begin{array}{l}8 \\
20\end{array}$ & $\begin{array}{l}12 \\
8.5\end{array}$ & $\begin{array}{l}6.4 \\
14\end{array}$ \\
\hline & 2 & $\begin{array}{l}40 \sim 46, \mathrm{XY},-8[3],-9[4],-13[3],-20[3] \\
{[\mathrm{cp} 7] / 46, \mathrm{XY}[20]}\end{array}$ & \begin{tabular}{|l|}
8 \\
20
\end{tabular} & $\begin{array}{l}13 \\
9\end{array}$ & $\begin{array}{l}6.4 \\
14\end{array}$ \\
\hline
\end{tabular}

*: Not in the karyotype. ${ }^{* *}$ : Under interferon therapy.

FISH: Fluorescence in situ hybridization

in cytogenetic preparations as well as in FISH study. -17 may be an important candidate marker to be followed by FISH in the course of CML since it is one of the additional minor-route chromosome abnormalities in the clonal evolution of $\mathrm{Ph}+\mathrm{CML}$ [1]. Furthermore, it leads to the loss of the p53 gene localized on $17 \mathrm{p}$, which is known to be involved in CML progression [1]. In patient 3, -8 was confirmed by FISH, but -20 could not be demonstrated by FISH despite its presence in the karyotype.

FISH results were in line with those of cytogenetics in some samples while not in others. This, once again, highlights the importance of concurrent use of different techniques (i.e. FISH and conventional cytogenetics) in cancer samples to increase the detection capability and improve the reliability of the results. Studies with larger numbers of patient samples and longer follow-up are required to establish the impact of certain monosomies on the disease course.

\section{Conflict of Interest Statement}

The authors of this paper have no conflicts of interest, including specific financial interests, relationships, and/or affiliations relevant to the subject matter or materials included.

Key Words: Cytogenetics, Marrow, Neoplasia, Chronic myeloid leukemia, Monosomy

Anahtar Sözcükler: Sitogenetik, Kemik iliği, Neoplazi, Kronik miyeloid lösemi, Monozomi 


\section{References}

1. Fioretos T, Johansson B. Chronic myeloid leukemia. In: Heim S, Mitelman F (eds). Cancer Cytogenetics. 3rd ed. Hoboken, NJ, USA, Wiley-Blackwell, 2009.

2. Öngören Ş, Tarkan-Argüden Y, Ar MC, Yllmaz Ş, Üre Ü, Kuru D, Eşkazan AE, Güven GS, Çetin G, Çırakoğlu A, Başlar Z, Deviren A, Aydın Y, Hacıhanefioğlu S, Ferhanoğlu B, Tüzüner N, Ülkü B, Soysal T. Clonal chromosomal abnormalities in Philadelphia-negative cells and their clinical significance in patients with chronic myeloid leukemia: results of a single center. Türkiye Klinikleri J Med Sci 2009;29:321-330.
3. Tarkan-Arguden Y, Ar MC, Yllmaz S, Ongoren S, Kuru D, Ure U, Cirakoglu A, Eskazan AE, Guven GS, Cetin G, Purisa S, Baslar Z, Deviren A, Aydın Y, Hacihanefioglu S, Ferhanoglu B, Tuzuner N, Ulku B, Soysal T. Cytogenetic clonal evolution in patients with chronic myeloid leukemia. Biotechnol Biotechnol Eq 2009;23:1515-1520.

4. International Standing Committee on Human Genetic Nomenclature. Neoplasia. In: Shaffer LF, Tommerup N (eds). ISCN: An International System for Human Cytogenetic Nomenclature. Basel, Switzerland, S. Karger, 2005. 